Article

\title{
Astataricusones A-D and Astataricusol A, Five New Anti-HBV Shionane-Type Triterpenes from Aster tataricus L. f.
}

Wen-Bing Zhou ${ }^{1,2, \dagger}$, Guang-Zhi Zeng ${ }^{1, \dagger}$, Hui-Min Xu ${ }^{1,2}$, Wen-Jun He ${ }^{1}$ and Ning-Hua Tan ${ }^{1, *}$

1 State Key Laboratory of Phytochemistry and Plant Resources in West China, Kunming Institute of Botany, Chinese Academy of Sciences, Heilongtan, Kunming 650201, China;

E-Mails: yaowufx2001@163.com (W.-B.Z.); gzh_zeng@mail.kib.ac.cn (G.-Z.Z.); cpuagua@126.com (H.-M.X.); hewenjun@mail.kib.ac.cn (W.-J.H.)

2 University of Chinese Academy of Sciences, Beijing 100049, China

$\dagger$ These authors contributed equally to this work.

* Author to whom correspondence should be addressed; E-Mail: nhtan@mail.kib.ac.cn; Tel./Fax: +86-871-6522-3800.

Received: 9 October 2013; in revised form: 13 November 2013 / Accepted: 15 November 2013 / Published: 25 November 2013

\begin{abstract}
Five new shionane-type triterpenes, astataricusones A-D (compounds 1-4) and astataricusol A (5), together with one known shionane-type triterpene 6 were obtained from the roots and rhizomes of Aster tataricus L. f. Their structures were elucidated on the basis of spectroscopic data, mainly NMR and MS data. The absolute configurations of $\mathbf{1}$ and $\mathbf{4}$ was determined by single crystal X-ray diffraction and CD analysis. Compound $\mathbf{2}$ showed inhibitory activity on $\mathrm{HBsAg}$ secretion with an $\mathrm{IC}_{50}$ value of $23.5 \mu \mathrm{M}$, while 2 and $\mathbf{6}$ showed inhibitory activities on $\mathrm{HBeAg}$ secretion with $\mathrm{IC}_{50}$ values of 18.6 and $40.5 \mu \mathrm{M}$, and cytotoxicity on HepG 2.2.15 cells with $\mathrm{CC}_{50}$ values of 172.4 and $137.7 \mu \mathrm{M}$, respectively. Compounds 2 and $\mathbf{6}$ also exhibited inhibitory activities on HBV DNA replication with $\mathrm{IC}_{50}$ values of 2.7 and $30.7 \mu \mathrm{M}$, respectively.
\end{abstract}

Keywords: Aster tataricus; shionane-type triterpenes; astataricusones A-D; astataricusol A; anti-HBV 


\section{Introduction}

Shionane-type triterpenoids possessing a unique all six-membered tetracyclic skeleton and 3-oxo-4-monomethyl moieties have been isolated only from Compositae plants [1]. The first studies on these compounds were done in the 1960s by Ourisson and Takahashi [2,3]. The stereostructures of rings A-D were determined by total synthesis in the 1970s by Ireland [4,5], but only six ones were reported from natural resources until now [6]. It has been reported that shionane-type triterpenes are the main constituents of Aster tataricus L. f. and have been shown to possess antitussive and expectorant activities [1,7,8]. In 2010 three new anti-HBV shionane-type triterpenes have been reported from A. tataricus by us [9]. As a continuation of our work on A. tataricus [9-13], we conducted further phytochemical studies on its roots and rhizomes. This has now led to the isolation of other five new shionane-type triterpenes, astataricusones A-D 1-4 and astataricusol A (5), and a known one, epishionol (6) (Figure 1). Herein we describe their isolation and structural elucidation, as well as their anti-HBV activity.

Figure 1. Structures of compounds 1-6.
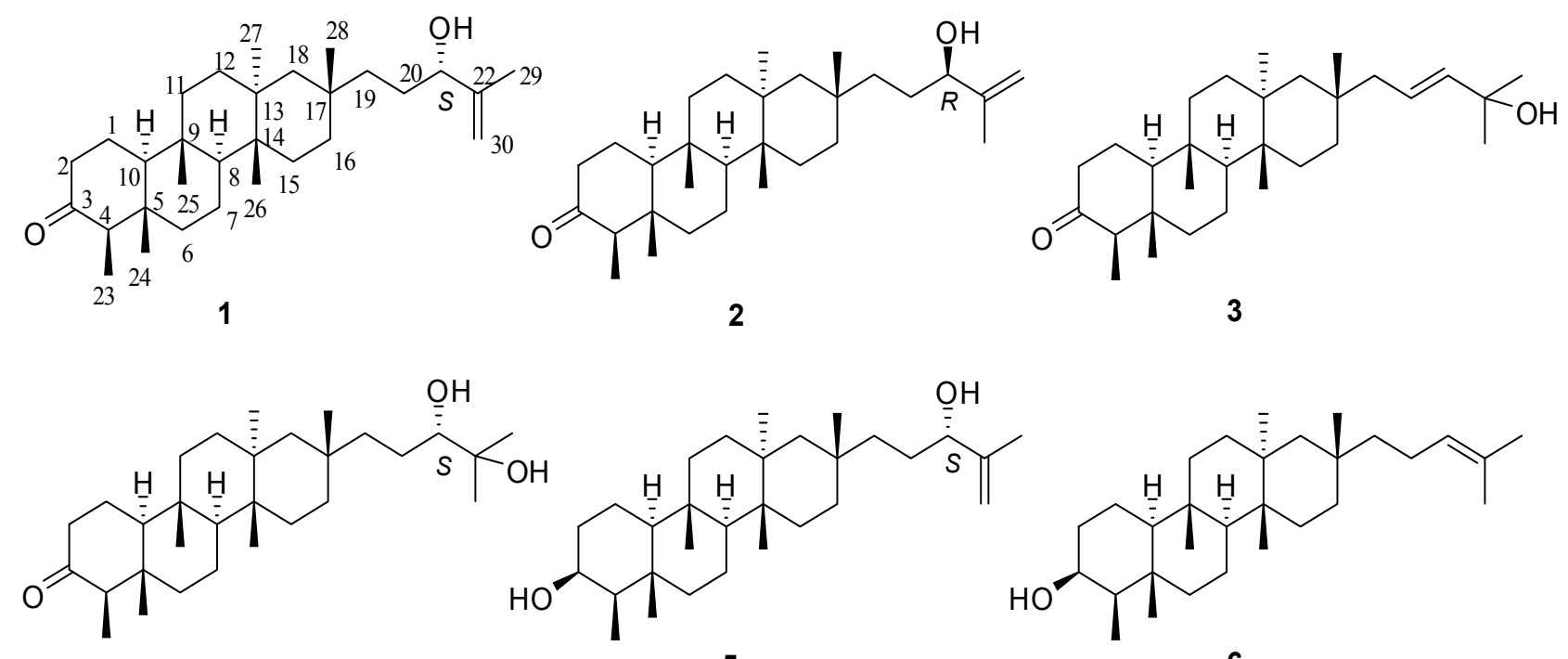

4

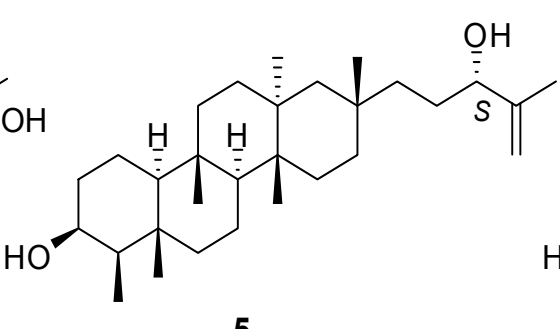

5

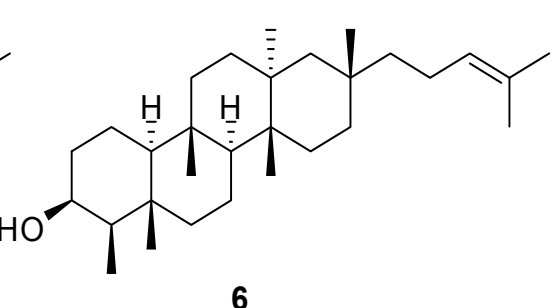

\section{Results and Discussion}

The EtOAc part of the A. tataricus $\mathrm{MeOH}$ extract was subjected to silica gel, $\mathrm{RP}-18$, and Sephadex LH-20 column chromatographies and semipreparative HPLC to yield five new shionanetype triterpenoids, named astataricusones A-D (compounds 1-4) and astataricusol A (5), and the known compound epishionol (6) $[14,15]$.

Compound 1 was obtained as colorless needles. It was determined to have six degrees of unsaturation corresponding to its molecular formula $\mathrm{C}_{30} \mathrm{H}_{50} \mathrm{O}_{2}$, as established by positive HREIMS ([M] $]^{+}$442.3808, calcd 442.3811) and NMR spectroscopies (Tables 1 and 2). The IR spectrum of 1 showed absorption bands for $\mathrm{OH}\left(3,498 \mathrm{~cm}^{-1}\right)$ and $\mathrm{C}=\mathrm{O}\left(1,697 \mathrm{~cm}^{-1}\right)$ functions. 
Table 1. ${ }^{13} \mathrm{C}-\mathrm{NMR}$ spectroscopic data for $\mathbf{1}-\mathbf{5}\left(\delta\right.$ in ppm, $\left.\mathrm{CDCl}_{3}, 100 \mathrm{MHz}\right)$.

\begin{tabular}{|c|c|c|c|c|c|}
\hline Position & 1 & 2 & 3 & 4 & 5 \\
\hline 1 & $22.3, \mathrm{CH}_{2}$ & $22.2, \mathrm{CH}_{2}$ & $22.3, \mathrm{CH}_{2}$ & $22.3, \mathrm{CH}_{2}$ & $15.8, \mathrm{CH}_{2}$ \\
\hline 2 & $41.4, \mathrm{CH}_{2}$ & $41.4, \mathrm{CH}_{2}$ & $41.4, \mathrm{CH}_{2}$ & $41.4, \mathrm{CH}_{2}$ & $35.2, \mathrm{CH}_{2}$ \\
\hline 3 & $213.3, \mathrm{C}$ & $213.1, \mathrm{C}$ & $213.2, \mathrm{C}$ & $213.3, \mathrm{C}$ & 72.7, CH \\
\hline 4 & $58.1, \mathrm{CH}$ & $58.1, \mathrm{CH}$ & $58.1, \mathrm{CH}$ & $58.2, \mathrm{CH}$ & $49.1, \mathrm{CH}$ \\
\hline 5 & $42.1, \mathrm{C}$ & $42.1, \mathrm{C}$ & $42.1, \mathrm{C}$ & $42.1, \mathrm{C}$ & $37.8, \mathrm{C}$ \\
\hline 6 & $41.0, \mathrm{CH}_{2}$ & 41.1, $\mathrm{CH}_{2}$ & 41.0, $\mathrm{CH}_{2}$ & 41.1, $\mathrm{CH}_{2}$ & 41.6, $\mathrm{CH}_{2}$ \\
\hline 7 & 17.8, $\mathrm{CH}_{2}$ & 17.8, $\mathrm{CH}_{2}$ & 17.9, $\mathrm{CH}_{2}$ & 17.9, $\mathrm{CH}_{2}$ & 17.2, $\mathrm{CH}_{2}$ \\
\hline 8 & $49.8, \mathrm{CH}$ & $49.8, \mathrm{CH}$ & $49.8, \mathrm{CH}$ & $49.9, \mathrm{CH}$ & $49.9, \mathrm{CH}$ \\
\hline 9 & $38.4, \mathrm{C}$ & $38.4, \mathrm{C}$ & $38.4, \mathrm{C}$ & $38.4, \mathrm{C}$ & $38.1, \mathrm{C}$ \\
\hline 10 & $59.5, \mathrm{CH}$ & $59.6, \mathrm{CH}$ & $59.5, \mathrm{CH}$ & 59.6, CH & $61.5, \mathrm{CH}$ \\
\hline 11 & $35.2, \mathrm{CH}_{2}$ & $35.2, \mathrm{CH}_{2}$ & $35.2, \mathrm{CH}_{2}$ & $35.2, \mathrm{CH}_{2}$ & $35.1, \mathrm{CH}_{2}$ \\
\hline 12 & $32.2, \mathrm{CH}_{2}$ & $32.2, \mathrm{CH}_{2}$ & 32.1, $\mathrm{CH}_{2}$ & $32.2, \mathrm{CH}_{2}$ & $32.4, \mathrm{CH}_{2}$ \\
\hline 13 & $36.8, \mathrm{C}$ & $36.8, \mathrm{C}$ & $36.9, \mathrm{C}$ & $36.9, \mathrm{C}$ & $36.8, \mathrm{C}$ \\
\hline 14 & $38.5, \mathrm{C}$ & $38.5, \mathrm{C}$ & $38.4, \mathrm{C}$ & $38.6, \mathrm{C}$ & $38.6, \mathrm{C}$ \\
\hline 15 & 29.1, $\mathrm{CH}_{2}$ & 29.1, $\mathrm{CH}_{2}$ & 29.2, $\mathrm{CH}_{2}$ & 29.1, $\mathrm{CH}_{2}$ & 29.1, $\mathrm{CH}_{2}$ \\
\hline 16 & 34.7, $\mathrm{CH}_{2}$ & $34.5, \mathrm{CH}_{2}$ & $33.8, \mathrm{CH}_{2}$ & $34.7, \mathrm{CH}_{2}$ & $34.7, \mathrm{CH}_{2}$ \\
\hline 17 & $31.3, \mathrm{C}$ & $31.4, \mathrm{C}$ & $32.1, \mathrm{C}$ & $31.6, \mathrm{C}$ & $31.4, \mathrm{C}$ \\
\hline 18 & $44.4, \mathrm{CH}_{2}$ & $44.4, \mathrm{CH}_{2}$ & 45.3, $\mathrm{CH}_{2}$ & $44.5, \mathrm{CH}_{2}$ & $44.5, \mathrm{CH}_{2}$ \\
\hline 19 & $38.9, \mathrm{CH}_{2}$ & $38.8, \mathrm{CH}_{2}$ & $45.8, \mathrm{CH}_{2}$ & $26.5, \mathrm{CH}_{2}$ & $38.9, \mathrm{CH}_{2}$ \\
\hline 20 & 29.7, $\mathrm{CH}_{2}$ & 25.6, $\mathrm{CH}_{2}$ & 124.2, $\mathrm{CH}$ & $40.5, \mathrm{CH}_{2}$ & 29.8, $\mathrm{CH}_{2}$ \\
\hline 21 & 76.9, CH & $90.5, \mathrm{CH}$ & $140.7, \mathrm{CH}$ & $79.5, \mathrm{CH}$ & 77.0, $\mathrm{CH}$ \\
\hline 22 & $147.4, \mathrm{C}$ & $143.5, \mathrm{C}$ & $70.8, \mathrm{C}$ & 73.2, C & $147.4, \mathrm{C}$ \\
\hline 23 & $6.8, \mathrm{CH}_{3}$ & $6.8, \mathrm{CH}_{3}$ & $6.8, \mathrm{CH}_{3}$ & $6.8, \mathrm{CH}_{3}$ & $11.6, \mathrm{CH}_{3}$ \\
\hline 24 & 14.6, $\mathrm{CH}_{3}$ & 14.6, $\mathrm{CH}_{3}$ & 14.6, $\mathrm{CH}_{3}$ & 14.6, $\mathrm{CH}_{3}$ & $16.4, \mathrm{CH}_{3}$ \\
\hline 25 & $19.6, \mathrm{CH}_{3}$ & $19.5, \mathrm{CH}_{3}$ & 19.6, $\mathrm{CH}_{3}$ & $19.6, \mathrm{CH}_{3}$ & $20.0, \mathrm{CH}_{3}$ \\
\hline 26 & $15.1, \mathrm{CH}_{3}$ & $15.1, \mathrm{CH}_{3}$ & $15.1, \mathrm{CH}_{3}$ & $15.2, \mathrm{CH}_{3}$ & 15.0, $\mathrm{CH}_{3}$ \\
\hline 27 & $20.5, \mathrm{CH}_{3}$ & $20.5, \mathrm{CH}_{3}$ & 21.0, $\mathrm{CH}_{3}$ & 20.6, $\mathrm{CH}_{3}$ & 20.6, $\mathrm{CH}_{3}$ \\
\hline 28 & $33.0, \mathrm{CH}_{3}$ & $32.7, \mathrm{CH}_{3}$ & $32.9, \mathrm{CH}_{3}$ & $32.9, \mathrm{CH}_{3}$ & $33.0, \mathrm{CH}_{3}$ \\
\hline 29 & $17.3, \mathrm{CH}_{3}$ & 17.0, $\mathrm{CH}_{3}$ & 29.9, $\mathrm{CH}_{3}$ & $23.2, \mathrm{CH}_{3}$ & $17.3, \mathrm{CH}_{3}$ \\
\hline 30 & $111.2, \mathrm{CH}_{2}$ & $114.6, \mathrm{CH}_{2}$ & $29.9, \mathrm{CH}_{3}$ & $26.5, \mathrm{CH}_{3}$ & $111.2, \mathrm{CH}_{2}$ \\
\hline
\end{tabular}

The ${ }^{13} \mathrm{C}$-NMR spectrum of 1 displayed 30 carbon signals, corresponding to seven methyls $\left(\delta_{\mathrm{C}} 6.8\right.$, 14.6, 15.1, 17.3, 19.6, 20.5, 33.0), twelve methylenes (including one olefinic carbon $\left(\delta_{\mathrm{C}} 111.2\right)$ ), four methines (including one oxygenated $\mathrm{CH}\left(\delta_{\mathrm{C}} 76.9\right)$ and seven quaternary carbons (including one keto carbonyl $\left(\delta_{\mathrm{C}} 213.3\right)$ and one olefinic carbon $\left.\left(\delta_{\mathrm{C}} 147.4\right)\right)$ (Table 1$)$. The ${ }^{1} \mathrm{H}-\mathrm{NMR}$ spectrum showed one secondary methyl $\left(\delta_{\mathrm{H}} 0.84,3 \mathrm{H}, \mathrm{d}, J=6.6 \mathrm{~Hz}\right)$ and six tertiary methyls $\left(\delta_{\mathrm{H}} 0.68,0.89,1.08,1.69\right.$ (each $3 \mathrm{H}, \mathrm{s}), 0.86(6 \mathrm{H}, \mathrm{s})$ ) (Table 2). The above facts suggested that $\mathbf{1}$ was a tetracyclic triterpenoid with a keto carbonyl group and one terminal double bond. Comparison of the ${ }^{1} \mathrm{H}$ and ${ }^{13} \mathrm{C}-\mathrm{NMR}$ data of $\mathbf{1}$ with those of shionone [16] indicated that 1 was similar to shionone in rings $\mathrm{A}-\mathrm{D}$, suggesting that the keto carbonyl group is attached to $\mathrm{C}-3$, which was supported by the $\mathrm{HMBC}$ correlations (Figure 2): $\mathrm{H}-23\left(\delta_{\mathrm{H}} 0.84,3 \mathrm{H}, \mathrm{d}, J=6.6 \mathrm{~Hz}\right) / \mathrm{C}-3\left(\delta_{\mathrm{C}} 213.3\right), \mathrm{H}-2\left(\delta_{\mathrm{H}} 2.36,1 \mathrm{H}\right.$ and $\left.2.27,1 \mathrm{H}, \mathrm{m}\right) / \mathrm{C}-3$, $\mathrm{H}-4\left(\delta_{\mathrm{H}} 2.21,1 \mathrm{H}, \mathrm{q}, J=6.6 \mathrm{~Hz}\right) / \mathrm{C}-3 .{ }^{1} \mathrm{H}-\mathrm{NMR}$ signals of 1 at $\delta_{\mathrm{H}} 1.20(1 \mathrm{H}, \mathrm{H}-19), 1.57(1 \mathrm{H}, \mathrm{H}-19)$, $1.44(1 \mathrm{H}, \mathrm{H}-20), 1.57(1 \mathrm{H}, \mathrm{H}-20), 3.97(1 \mathrm{H}, \mathrm{t}, J=6.1 \mathrm{~Hz}, \mathrm{H}-21), 1.69$ (3H, s, H-29), $4.81(1 \mathrm{H}, \mathrm{s}$, 
$\mathrm{H}-30), 4.90(1 \mathrm{H}, \mathrm{s}, \mathrm{H}-30)$ and ${ }^{13} \mathrm{C}-\mathrm{NMR}$ signals at $\delta_{\mathrm{C}} 38.9(\mathrm{C}-19), 29.7$ (C-20), 76.9 (C-21), 147.4 (C-22), 17.3 (C-29), 111.2 (C-30) revealed that 1 possesses the side chain of $-\mathrm{CH}_{2}-\mathrm{CH}_{2}-$ $\mathrm{CH}(\mathrm{OH})-\mathrm{C}\left(=\mathrm{CH}_{2}\right) \mathrm{CH}_{3}$, which was confirmed by the HMBC correlations between $\mathrm{H}-21$ and $\mathrm{C}-19$, C-20, C-22, C-29, C-30, and H-29 and C-21, C-22, C-30, and also by the ${ }^{1} \mathrm{H}-{ }^{1} \mathrm{H}$ COSY correlation between H-20 and H-21 (Figure 2). More importantly, the HMBC correlation between H-28 and C-19 indicated that $\mathrm{C}-19$ was attached to $\mathrm{C}-17\left(\delta_{\mathrm{C}} 31.3\right)$. Therefore, the planar structure of 1 was established as shown in Figure 1.

Table 2. ${ }^{1} \mathrm{H}-\mathrm{NMR}$ spectroscopic data for $\mathbf{1}-\mathbf{5}$ ( $\delta$ in ppm, $J$ in $\mathrm{Hz}, \mathrm{CDCl}_{3}, 400 \mathrm{MHz}$ ).

\begin{tabular}{|c|c|c|c|c|c|}
\hline Position & 1 & 2 & 3 & 4 & 5 \\
\hline $1 \mathrm{a}$ & $1.95, \mathrm{~m}$ & $1.98, \mathrm{~m}$ & 1.98 , overlap & $1.98, \mathrm{~m}$ & 1.58 , overlap \\
\hline $1 \mathrm{~b}$ & 1.67 , overlap & 1.69 , overlap & 1.69 , overlap & 1.69 , overlap & 1.46 , overlap \\
\hline $2 a$ & $2.36, \mathrm{~m}$ & $2.39, \mathrm{~m}$ & $2.38, \mathrm{~m}$ & $2.39, \mathrm{~m}$ & $1.90, \mathrm{~m}$ \\
\hline $2 b$ & $2.27, \mathrm{~m}$ & $2.32, \mathrm{~m}$ & 2.30 , overlap & $2.30, \mathrm{~m}$ & - \\
\hline 3 & - & - & - & - & $3.73, \mathrm{~m}$ \\
\hline 4 & $2.21, \mathrm{q}(6.6)$ & $2.25, \mathrm{q}(6.6)$ & $2.25, \mathrm{q}(6.4)$ & $2.25, \mathrm{q}(6.7)$ & 1.25 , overlap \\
\hline $6 a$ & 1.69 , overlap & 1.74 , overlap & 1.72 , overlap & 1.72 , overlap & 1.72 , overlap \\
\hline $6 \mathrm{~b}$ & 1.20 , overlap & 1.25 , overlap & 1.26 , overlap & 1.25 , overlap & 0.92 , overlap \\
\hline $7 \mathrm{a}$ & 1.47 , overlap & $1.47, \mathrm{~m}$ & $1.49, \mathrm{~m}$ & 1.50 , overlap & - \\
\hline $7 b$ & 1.30 , overlap & 1.32 , overlap & 1.32, overlap & 1.32 , overlap & 1.37 , overlap \\
\hline 8 & 1.30 , overlap & 1.32 , overlap & 1.32 , overlap & 1.32 , overlap & 1.25 , overlap \\
\hline 10 & 1.54 , overlap & 1.60 , overlap & 1.60 , overlap & 1.60 , overlap & 0.94 , overlap \\
\hline $11 \mathrm{a}$ & 1.51 , overlap & 1.53 , overlap & 1.53 , overlap & 1.50 , overlap & 1.58 , overlap \\
\hline $11 \mathrm{~b}$ & $1.39, \mathrm{~m}$ & 1.42 , overlap & 1.40 , overlap & 1.41 , overlap & 1.37 , overlap \\
\hline $12 \mathrm{a}$ & 1.54 , overlap & 1.53 , overlap & 1.53 , overlap & 1.60 , overlap & 1.56 , overlap \\
\hline $12 \mathrm{~b}$ & 0.89 , overlap & 0.90 , overlap & 0.91 , overlap & 0.91 , overlap & 0.87 , overlap \\
\hline 15 & $1.27, \mathrm{~m}$ & 1.25 , overlap & 1.32 , overlap & 1.32 , overlap & 1.25 , overlap \\
\hline $16 \mathrm{a}$ & 1.61 , overlap & 1.60, overlap & 1.60 , overlap & 1.66 , overlap & 1.61 , overlap \\
\hline $16 \mathrm{~b}$ & $1.35, \mathrm{~m}$ & 1.32, overlap & 1.40 , overlap & 1.41 , overlap & 1.37 , overlap \\
\hline $18 \mathrm{a}$ & 1.17 , overlap & $1.21, \mathrm{~d}(14.4)$ & $1.21, \mathrm{~d}(14.7)$ & 1.25 , overlap & 1.19 , overlap \\
\hline $18 \mathrm{~b}$ & 1.08 , overlap & $1.08, \mathrm{~d}(14.4)$ & $1.09, \mathrm{~d}(14.7)$ & 1.07 , overlap & 1.08 , overlap \\
\hline $19 \mathrm{a}$ & 1.57 , overlap & $1.78, \mathrm{~m}$ & 2.33 , overlap & 1.54 , overlap & 1.59 , overlap \\
\hline $19 \mathrm{~b}$ & 1.20 , overlap & 1.11, overlap & 1.98 , overlap & 1.23 , overlap & 1.19 , overlap \\
\hline $20 \mathrm{a}$ & 1.57 , overlap & 1.60 , overlap & $5.66, \mathrm{~m}$ & 1.66 , overlap & 1.61 , overlap \\
\hline $20 \mathrm{~b}$ & 1.44 , overlap & 1.39 , overlap & - & 1.54 , overlap & 1.46 , overlap \\
\hline 21 & $3.97, \mathrm{t}(6.1)$ & $4.26, \mathrm{t}(6.8)$ & $5.58, \mathrm{~d}(15.7)$ & $3.28, \mathrm{~d}(9.7)$ & $3.99, \mathrm{t}(6.2)$ \\
\hline 23 & $0.84, \mathrm{~d}(6.6)$ & $0.86, \mathrm{~d}(6.6)$ & $0.87, \mathrm{~d}(6.4)$ & $0.87, \mathrm{~d}(6.7)$ & $0.93, \mathrm{~d}(7.3)$ \\
\hline 24 & $0.68, \mathrm{~s}$ & $0.71, \mathrm{~s}$ & $0.71, \mathrm{~s}$ & $0.71, \mathrm{~s}$ & $0.94, \mathrm{~s}$ \\
\hline 25 & $0.89, \mathrm{~s}$ & $0.91, \mathrm{~s}$ & $0.91, \mathrm{~s}$ & $0.92, \mathrm{~s}$ & $0.90, \mathrm{~s}$ \\
\hline 26 & 0.86 , overlap & $0.88, \mathrm{~s}$ & 0.88 , overlap & $0.88, \mathrm{~s}$ & $0.87, \mathrm{~s}$ \\
\hline 27 & $1.08, \mathrm{~s}$ & $1.11, \mathrm{~s}$ & $1.13, \mathrm{~s}$ & $1.11, \mathrm{~s}$ & $1.08, \mathrm{~s}$ \\
\hline 28 & 0.86 , overlap & $0.88, \mathrm{~s}$ & 0.88 , overlap & $0.89, \mathrm{~s}$ & $0.87, \mathrm{~s}$ \\
\hline 29 & $1.69, \mathrm{~s}$ & $1.74, \mathrm{~s}$ & 1.32 , overlap & $1.22, \mathrm{~s}$ & $1.72, \mathrm{~s}$ \\
\hline $30 \mathrm{a}$ & $4.90, \mathrm{~s}$ & $5.05, \mathrm{~s}$ & 1.32 , overlap & $1.17, \mathrm{~s}$ & $4.92, \mathrm{~s}$ \\
\hline $30 \mathrm{~b}$ & $4.81, \mathrm{~s}$ & $5.02, \mathrm{~s}$ & - & - & $4.83, \mathrm{~s}$ \\
\hline
\end{tabular}


Figure 2. $\mathrm{Key}{ }^{1} \mathrm{H}-{ }^{1} \mathrm{H}$ COSY $(\boldsymbol{-})$ and $\mathrm{HMBC}(\mathrm{H} \rightarrow \mathrm{C})$ correlations of $\mathbf{1}-\mathbf{5}$.
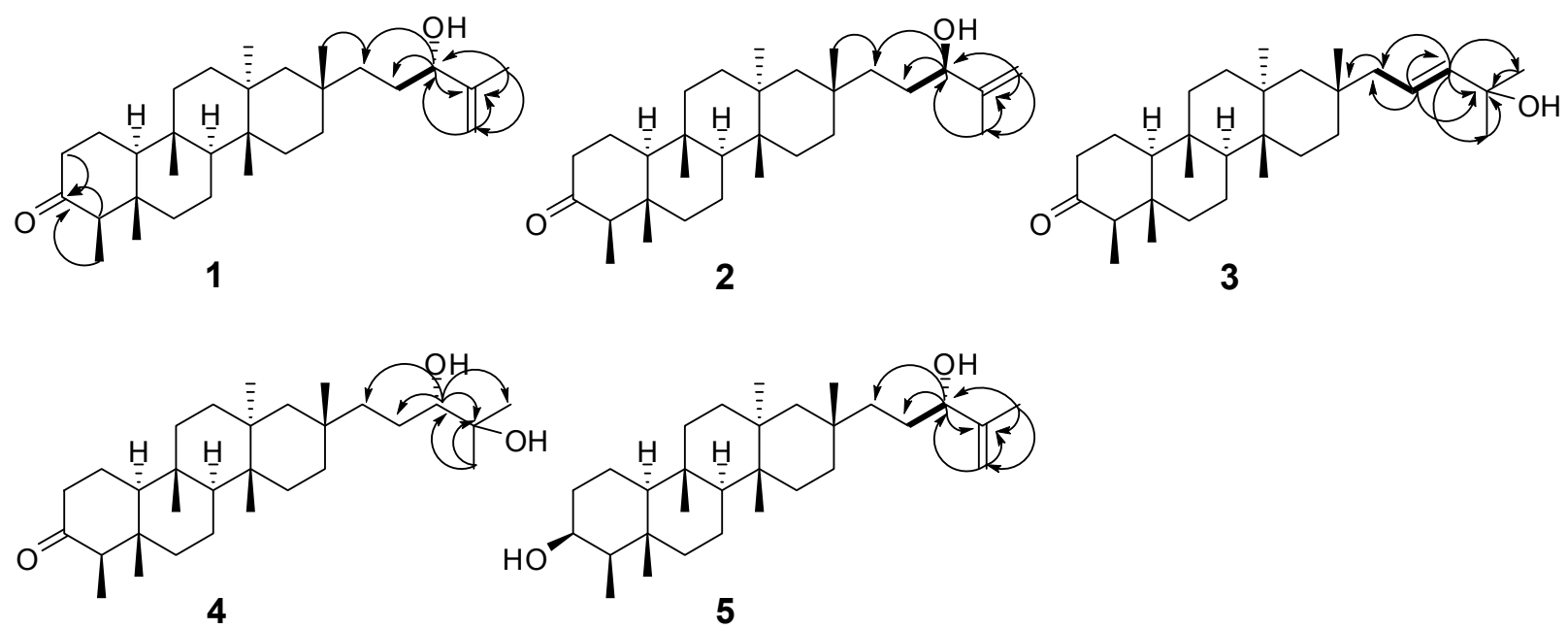

The negative Cotton effect $(-9.5)$ at $290 \mathrm{~nm}$ indicated the C-4 absolute configuration of 1 was $R$ by the octant rule. In the ROESY spectrum, H-23 showed correlations to H-24, H-24 to H-25, H-26 to H-28, $\mathrm{H}-27$ to $\mathrm{H}-19$, which indicated $\mathrm{H}-23, \mathrm{H}-24$ and $\mathrm{H}-25, \mathrm{H}-26$ and $\mathrm{H}-28, \mathrm{H}-27$ and $\mathrm{H}-19$ in the same orientation. To confirm the structure and determine its absolute configuration, 1 was crystallized from $\mathrm{MeOH}$ to afford a crystal of the orthorhombic space group $P 2_{1} 2_{1} 2_{1}$, which was analyzed by X-ray crystallography. The final refinement on the $\mathrm{CuK \alpha}$ data resulted in a Flack parameter of 0.1 (3), allowing unambiguous assignment of the absolute configuration (Figure 3, CCDC 926578) [17]. These results indicated that $\mathrm{H}-23, \mathrm{H}-24, \mathrm{H}-25, \mathrm{H}-26$ and $\mathrm{H}-28$ were $\beta$-oriented, and $\mathrm{H}-8, \mathrm{H}-10, \mathrm{H}-19$ and $\mathrm{H}-27$ were $\alpha$-oriented. Therefore the absolute configuration and structure of 1 were finally assigned, i.e., $(4 R, 5 S, 8 S, 9 S, 10 S, 13 S, 14 R, 17 S, 21 S)$-21-hydroxy-shion-22(30)-en-3-one, and the compound was named astataricusone $\mathrm{A}$.

Figure 3. X-ray crystallographic structure of 1.

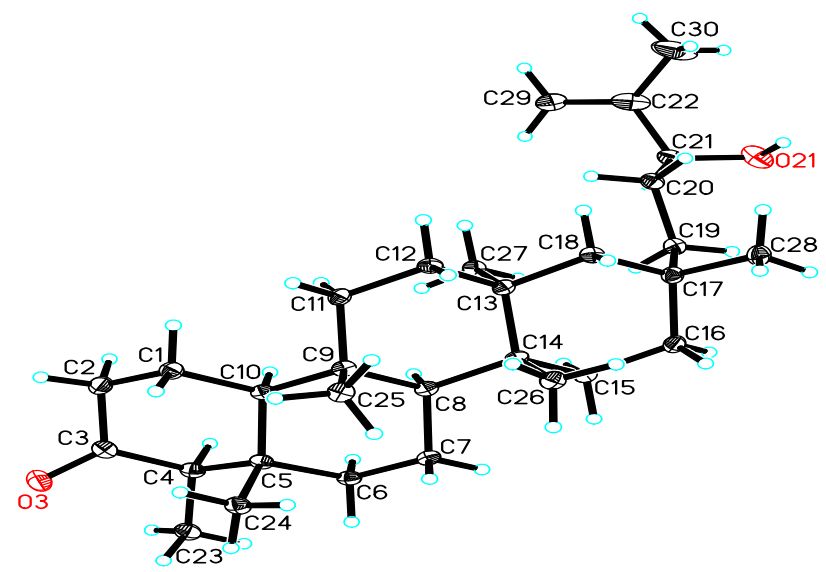

Compound 2 was obtained as white powder, and had the same planar structure with $\mathbf{1}$, based on the interpretation of 1D and 2D NMR data. Comparing the NMR data (Tables 1 and 2) with those of 1 revealed that the stereostructure of C-21 was different, which was supported by the signals of C-21 at $\delta_{\mathrm{C}} 76.9$ and $\mathrm{H}-21$ at $\delta_{\mathrm{H}} 3.97(1 \mathrm{H}, \mathrm{t}, J=6.1 \mathrm{~Hz})$ in 1 and was replaced by those of C-21 at $\delta_{\mathrm{C}} 90.5$ and $\mathrm{H}-21$ 
at $\delta_{\mathrm{H}} 4.26(1 \mathrm{H}, \mathrm{t}, J=6.8 \mathrm{~Hz})$ in 2 . It allowed the assignment of the absolute configuration at $\mathrm{C}-21$ as $(R)$ in 2. Thus, the structure of 2 was established as $(4 R, 5 S, 8 S, 9 S, 10 S, 13 S, 14 R, 17 S, 21 R)$-21-hydroxyshion-22(30)-en-3-one, and it was named astataricusone B.

Compound 3 was obtained as a white powder. Its molecular formula was determined as $\mathrm{C}_{30} \mathrm{H}_{50} \mathrm{O}_{2}$ by HREIMS at $m / z 442.3824[\mathrm{M}]^{+}$(calcd for 442.3811). Comparing the NMR data (Tables 1 and 2) with those of 22-methoxy-shion-20-en-3-one [9] revealed the following differences: the presence of a hydroxyl group at C-22 was supported by the HMBC correlations between $\mathrm{H}-20\left(\delta_{\mathrm{H}} 5.66,1 \mathrm{H}, \mathrm{m}\right)$, $\mathrm{H}-21\left(\delta_{\mathrm{H}} 5.58,1 \mathrm{H}, \mathrm{d}, J=15.7 \mathrm{~Hz}\right), \mathrm{H}-29,30\left(\delta_{\mathrm{H}} 1.32,6 \mathrm{H}\right)$ and C-22 in $\mathbf{3}$, but a methoxy group at C-22 in 22-methoxy-shion-20-en-3-one. The configuration of $\mathbf{3}$ was established to be identical to $\mathbf{1}$ based on the similar ROESY correlations and CD data. The $J_{\mathrm{H}-20} / \mathrm{H}-21$ value $(15.7 \mathrm{~Hz})$ was indicative of $20 E$ geometry. Hence, the structure of 3 was assigned as $(4 R, 5 S, 8 S, 9 S, 10 S, 13 S, 14 R, 17 S, 20 E)-22-$ hydroxy-shion-20-en-3-one, and the compound was named astataricusone C.

Compound 4 was obtained as a white powder. Its molecular formula was determined as $\mathrm{C}_{30} \mathrm{H}_{52} \mathrm{O}_{3}$ by HREIMS at $m / z 460.3922[\mathrm{M}]^{+}$(calcd. for 460.3916). Comparing the NMR data with 1 indicated that $\mathbf{4}$ had a different side chain. The structure of $\mathbf{4}$ was established as 21,22-dihydroxy-shion-3-one based on the 1D and 2D NMR data. The stereochemistry at C-21 were amenable to CD analysis with dimolybdenum tetracetate. Acyclic 1,2-diols can form a complex with $\mathrm{Mo}_{2}(\mathrm{AcO})_{4}$ and the complex produces a significant induced CD spectrum (ICD). According to the rule proposed by Snatzke [18,19], the diagnostic band at around $310 \mathrm{~nm}$ has the same sign of the $\mathrm{O}-\mathrm{C}-\mathrm{C}-\mathrm{O}$ dihedral angle in the favored conformation in the 1,2-diol moiety. So assignment of the absolute configuration of the chiral centers in the 1,2-diol moiety could be given based on the sign of the band at arond $310 \mathrm{~nm}$ of the ICD spectrum. In particular an $S$-monosubstituted glycol gives rise to a positive Cotton effect at around $310 \mathrm{~nm}$. Thus, the positive sign observed at $315 \mathrm{~nm}$ in the mixture ICD spectrum of $\mathbf{4}$ and $\mathrm{Mo}_{2}(\mathrm{OAc})_{4}$ (Figure 4) allowed to assign the $S$-configuration to C-21 in $\mathbf{4}$. Therefore, the structure of $\mathbf{4}$ was established as $(4 R, 5 S, 8 S, 9 S, 10 S, 13 S, 14 R, 17 S, 21 S)$-21,22-dihydroxy-shion-3-one, and it was named astataricusone D.

Figure 4. ICD spectrum of the in situ-formed Mo-complex of 4 and $\mathrm{Mo}_{2}(\mathrm{OAc})_{4}$ in a ratio of 1:1.2.

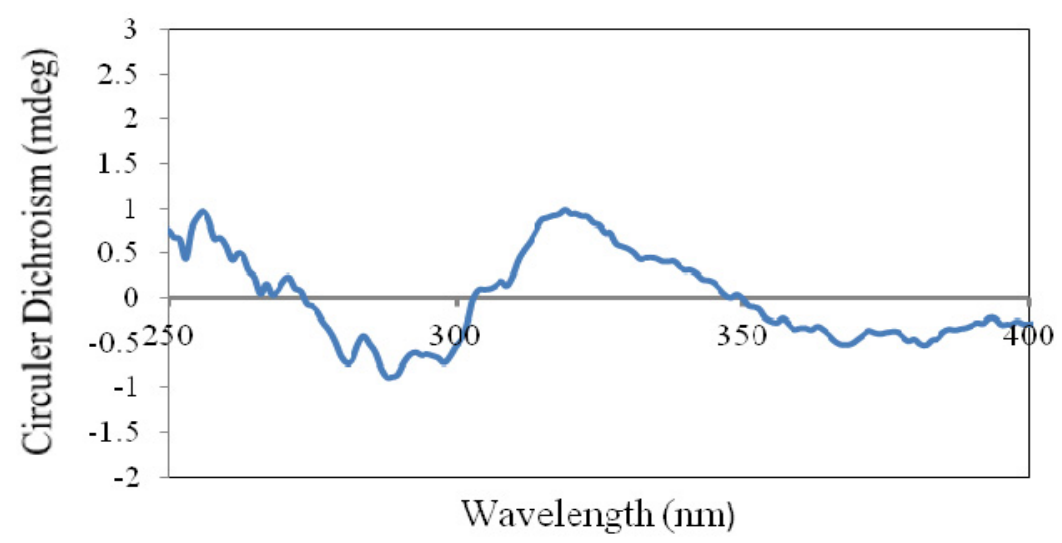

Compound 5 was assigned the molecular formula $\mathrm{C}_{30} \mathrm{H}_{52} \mathrm{O}_{2}$ by its HREIMS data at $\mathrm{m} / z=444.3973$ $[\mathrm{M}]^{+}$(calcd. 444.3967). Comparing the NMR data with $\mathbf{6}[14,15]$ and $\mathbf{1}, \mathbf{5}$ had the same cyclic skeleton as $\mathbf{6}$ and the same side chain as 1, which was supported by the HMBC correlations between H-21 $\left(\delta_{\mathrm{H}} 3.99,1 \mathrm{H}, \mathrm{t}, J=6.2 \mathrm{~Hz}\right)$ and $\mathrm{C}-29\left(\delta_{\mathrm{C}} 17.3\right), \mathrm{C}-20\left(\delta_{\mathrm{C}} 29.8\right), \mathrm{C}-19\left(\delta_{\mathrm{C}} 38.9\right), \mathrm{C}-30\left(\delta_{\mathrm{C}} 111.2\right)$, and $\mathrm{H}-30\left(\delta_{\mathrm{H}} 4.92,1 \mathrm{H}, \mathrm{s}\right)$ and $\mathrm{C}-21\left(\delta_{\mathrm{C}} 77.0\right)$. The configuration of 5 was established to be identical to 1 
based on the similar ROESY correlations and $\mathbf{6}$ based on the similar CD data. Therefore, the structure of 5 was established as $(3 S, 4 R, 5 S, 8 S, 9 S, 10 S, 13 S, 14 R, 17 S, 21 S)$-shion-22(30)-en-3,21-diol, and the compound was named astataricusol A.

Compounds 1-6 were tested for anti-HBV activity in HBV antigen secretion and DNA replication of HepG 2.2.15 cells using the literature methods [20-22]. Results indicated that $\mathbf{2}$ showed inhibitory activity on $\mathrm{HBsAg}$ secretion with an $\mathrm{IC}_{50}$ value of $23.5 \mu \mathrm{M}$, while $\mathbf{2}$ and $\mathbf{6}$ showed inhibitory activities on $\mathrm{HBeAg}$ secretion with $\mathrm{IC}_{50}$ values of 18.6 and $40.5 \mu \mathrm{M}$, and cytotoxicity on HepG 2.2.15 cells with $\mathrm{CC}_{50}$ values of 172.4 and $137.7 \mu \mathrm{M}$, respectively; 2 and $\mathbf{6}$ exhibited inhibitory activities on HBV DNA replication with $\mathrm{IC}_{50}$ values of 2.7 and $30.7 \mu \mathrm{M}$.

\section{Experimental}

\subsection{General}

Melting points were determined on a TECH X-4 micro melting point apparatus without correction. Optical rotations were measured with a Horiba SEPA-300 polarimeter (Horiba, Kyoto, Japan). UV spectra were obtained using a Shimadzu UV-2401A spectrophotometer (Shimadzu, Kyoto, Japan). IR spectra were obtained by a Tenor 27 spectrophotometer (Bruker, Karlsruhe, Germany) using $\mathrm{KBr}$ pellets. $\mathrm{CD}$ spectra were recorded with an Applied Photophysics Chirascan spectrometer (Applied Photophysics Ltd., London, UK). 1D and 2D NMR spectra were run on Bruker DRX-500 or AM-400 spectrometers (Bruker, Karlsruhe, Germany) with TMS as internal standard; coupling constants were expressed in Hertz and chemical shifts $(\delta)$ were expressed in ppm with reference to the solvent signals. Mass spectra were recorded on a VG Autospec-3000 spectrometer (VG, Manchester, UK) or an API QSTAR Pulsar TOF spectrometer (AB-MDS Sciex, Concord, ON, Canada).

Analytical or semipreparative HPLC was performed on an Agilent 1100 liquid chromatograph (Agilent, Santa Clara, CA, USA) with a Zorbax Eclipse-C $\mathrm{C}_{18}(4.6 \mathrm{~mm} \times 150 \mathrm{~mm} ; 9.4 \mathrm{~mm} \times 250 \mathrm{~mm}$; $5 \mu \mathrm{M}$ ). Column chromatography was performed on silica-gel (200-300 mesh, Qingdao Yu-Ming-Yuan Chemical Co. Ltd., Qingdao, China), Sephadex LH-20 (Pharmacia Fine Chemical Co., Uppsala, Sweden), Lichroprep RP-18 gel (40-63 $\mu \mathrm{M}$, Merck, Darmstadt, Germany). Fractions were monitored by TLC (GF254, Qingdao Yu-Ming-Yuan Chemical Co. Ltd., Qingdao, China), and spots were visualized by heating Si gel plates sprayed with $5 \% \mathrm{H}_{2} \mathrm{SO}_{4}$ in $\mathrm{EtOH}$.

\subsection{Plant Material}

The roots and rhizomes of Aster tataricus L. f. was commercially purchased from the Yunnan Lv-Sheng Pharmaceutical Co. Ltd. (Kunming, China) and identified by Prof. Xi-Wen Li at Kunming Institute of Botany (voucher No. 200704).

\subsection{In Vitro Anti-HBV Assay}

The in vitro anti-HBV activity of compounds 1-6 were analyzed by the secretion of HBV antigen and DNA replication from the HepG 2.2.15 cell line. The toxicity of the compounds was evaluated by the sulforhodamine B method. DMSO alone was used as a solvent control. All the compounds were tested for their anti-HBV activity with the highest concentration of $20 \mu \mathrm{g} / \mathrm{mL}$. Lamivudine (3TC) was 
used as the positive control.

\subsubsection{Cell Line and Cell Culture}

The widely used HepG 2.2.15 cell line was applied for the assay of anti-HBV activity. In this study, the HepG 2.2.15 cell lines, which were stably transfected with the HBV genome, were a gift from Prof. Yong-Tang Zheng, Kunming Institute of Zoology, Chinese Academy of Sciences and cultured in RPMI-1640 (Gibco, Carlsbad, CA, USA) medium supplemented with 10\% FBS (Haoyang Biological Manufacture Co., Ltd. Tianjin, China) and $400 \mu \mathrm{g} / \mathrm{mL}$ G148 (Calbiochem, San Diego, CA, USA). All cultures were maintained at $37^{\circ} \mathrm{C}$ in a moist atmosphere containing $5 \% \mathrm{CO}_{2}$.

\subsubsection{Analysis of Secreted HBV Antigens}

Inhibitory activity of compounds $\mathbf{1}-\mathbf{6}$ on the secretion of HBV antigens in HepG 2.2.15 cells was evaluated with an ELISA method (Kehua Bio-engineering Co., Ltd, Shanghai, China). The procedures were performed according to that described in the previous literature [20,21] with some modifications. Cells were seeded in 96-well microplates at a density of $5 \times 10^{4}$ cells $/ \mathrm{mL}$ and cultured at $37{ }^{\circ} \mathrm{C}$, $5 \% \mathrm{CO}_{2}$ for $24 \mathrm{~h}$. Different concentrations of compounds were added in the wells. The medium was replaced every 3 days with fresh medium and compounds. After cultured for 12 days, the supernatants were collected, and the levels of HBsAg and HBeAg in the supernatants were evaluated according to the manufacturer's instructions. The absorbance was measured at 450/630 nm using a microplate reader (SpectraMax 190, Molecular Devices, San Francisco, CA, USA).

\subsubsection{Assay for HBV DNA Replication}

Inhibitory activity of compounds 2 and $\mathbf{6}$ on HBV DNA replication in HepG 2.2.15 cells was examined by a fluorescence quantitative PCR kit (Shanghai Fuxing Bio-engineering Co., Ltd, Shanghai, China). After the cells were treated with or without the compounds for 12 days, the HBV DNA level in HepG2.2.15 cells was evaluated according to the manufacturer's instruction with a Real-Time PCR Systems (ABI7500, Applied Biosystems, Foster city, CA, USA).

\subsubsection{Cytotoxicity Assay}

Cytotoxicity of compounds 1-6 on HepG 2.2.15 cells was tested by a sulforhodamine B method [22] (SRB, Sigma, St. Louis, MO, USA). Firstly, HepG 2.2.15 cells were seeded in a 96-well microplate for $24 \mathrm{~h}$. Compounds, dissolved in DMSO and diluted with the medium, were placed in each well and incubated for another $72 \mathrm{~h}$ at $37{ }^{\circ} \mathrm{C}$. Then cells were fixed with $50 \%$ ice-cold trichloroacetic acid at $4{ }^{\circ} \mathrm{C}$ for $1 \mathrm{~h}$ and stained with $0.4 \% \mathrm{SRB}$ in $1 \%$ acetic acid solution for $15 \mathrm{~min}$. After removal of excessive dye, SRB was resuspended in $10 \mathrm{mM}$ Tris buffer, and the absorbance was measured at $560 \mathrm{~nm}$ with the microplate reader above-mentioned. 


\subsection{Extraction and Isolation}

The air-dried roots and rhizomes $(50 \mathrm{~kg})$ of Aster tataricus were extracted with methanol at reflux for three times. The $\mathrm{MeOH}$ extract $(13 \mathrm{~kg}$ ) was concentrated under reduced pressure, and then partitioned sequentially by EtOAc and $n-\mathrm{BuOH}$. The dried EtOAc part $(2 \mathrm{~kg}$ ) was subjected to silica gel column chromatography $\left(\mathrm{CC}, 10 \mathrm{~kg}\right.$ ) and eluted by a gradient of $\mathrm{CHCl}_{3} / \mathrm{MeOH}$. The fraction from $\mathrm{CHCl}_{3}(840 \mathrm{~g})$ was subjected to silica gel CC (1:0-5:1 petroleum ether/acetone), giving fractions (Fr.) 1-6. Fr. 4 (40 g, 20:1 petroleum ether/acetone) was resubmitted to chromatography over silica gel (30:1-10:1 petroleum ether/acetone) to yield Fr. 4/1-4/3. Fr. 4/2 (20:1 petroleum ether/acetone, $25 \mathrm{~g}$ ) was purified by Sephadex LH-20 (1:1 chloroform/methanol) and then submitted to additional silica gel CC (20:1, 10:1, and 5:1 petroleum ether/ethyl acetate) to afford Fr. 4/2/1-4/2/3. Fr. 4/2/2 (10:1 petroleum ether/ethyl acetate, $10 \mathrm{~g}$ ) was purified by $\mathrm{CC}$ on $\mathrm{RP}-18$ with $\mathrm{MeOH}-\mathrm{H}_{2} \mathrm{O}$ (40:60-1:0) to yield Fr. 4/2/2/1-4/2/2/4. Fr. 4/2/2/3 (1.55 g) was purified by semipreparative HPLC with $\mathrm{MeCN}-\mathrm{H}_{2} \mathrm{O}(75: 25)$ at a flow rate of $10 \mathrm{~mL} / \mathrm{min}$ (UV detector, $205 \mathrm{~nm}$ ) to yield compounds $1\left(t_{R}=15.5 \mathrm{~min}, 152 \mathrm{mg}\right.$ ), $2\left(t_{R}=16.4 \mathrm{~min}, 121 \mathrm{mg}\right), 3\left(t_{R}=17.5 \mathrm{~min}, 45 \mathrm{mg}\right)$ and $\mathbf{6}\left(t_{\mathrm{R}}=21.0 \mathrm{~min}, 75 \mathrm{mg}\right)$. Fr. 4/3 (10:1 petroleum ether/acetone, $8 \mathrm{~g})$ was purified by $\mathrm{CC}$ on $\mathrm{RP}-18\left(\mathrm{MeOH}-\mathrm{H}_{2} \mathrm{O}, 30: 70-1: 0\right)$ to yield $\mathrm{Fr}$. $4 / 3 / 1-4 / 3 / 4$. Compounds $4\left(t_{R}=17.1 \mathrm{~min}, 5 \mathrm{mg}\right)$ and $5\left(t_{R}=23.0 \mathrm{~min}, 7 \mathrm{mg}\right)$ were obtained from Fr. $4 / 3 / 3$ by subsequent silica gel CC (petroleum ether/acetone, 15:1) and semipreparative HPLC with $\mathrm{MeCN}-\mathrm{H}_{2} \mathrm{O}(70: 30)$ at a flow rate of $10 \mathrm{~mL} / \mathrm{min}$ (UV detector, $205 \mathrm{~nm}$ ).

Astataricusone $A(\mathbf{1})$ : colorless needles; $\mathrm{mp} 235-236{ }^{\circ} \mathrm{C} ;[\alpha]_{\mathrm{D}}^{24.3}-33.8$ (c 1.33, MeOH); UV (MeOH) $\lambda_{\max }(\log \varepsilon) 202(3.12) \mathrm{nm} ; \mathrm{CD}(\mathrm{c} 0.64, \mathrm{MeOH}) \lambda(\Delta \varepsilon) 290(-9.5) \mathrm{nm}$; IR (KBr) $v_{\max }$ 3,498, 2,955, 2,927, 1,697, 1,467, 1,451, 1,390, 1,074, $894 \mathrm{~cm}^{-1} ;{ }^{1} \mathrm{H}-\mathrm{NMR}\left(400 \mathrm{MHz}, \mathrm{CDCl}_{3}\right)$ and ${ }^{13} \mathrm{C}-\mathrm{NMR}$ $\left(100 \mathrm{MHz}, \mathrm{CDCl}_{3}\right.$ ), see Tables 1 and 2; HREIMS $m / z 442.3808[\mathrm{M}]^{+}$(calcd. for $\mathrm{C}_{30} \mathrm{H}_{50} \mathrm{O}_{2}, 442.3811$ ).

Astataricusone $B(2)$ : white powder; $[\alpha]_{\mathrm{D}}^{23.7}-5.9$ (c 0.27, MeOH); UV (MeOH) $\lambda_{\max }(\log \varepsilon) 209$ (2.87) nm; $\mathrm{CD}(\mathrm{c} 0.61, \mathrm{MeOH}) \lambda(\Delta \varepsilon) 290(-2.5) \mathrm{nm}$; IR (KBr) $v_{\max } 3,441,3,425,2,961,2,926,1,704,1,629$, 1,262, 1,097, 1,024, $803 \mathrm{~cm}^{-1}$; ${ }^{1} \mathrm{H}-\mathrm{NMR}\left(400 \mathrm{MHz}, \mathrm{CDCl}_{3}\right)$ and ${ }^{13} \mathrm{C}-\mathrm{NMR}\left(100 \mathrm{MHz}, \mathrm{CDCl}_{3}\right)$, see Tables 1 and 2; HREIMS $m / z$ 442.3804 [M] (calcd. for $\mathrm{C}_{30} \mathrm{H}_{50} \mathrm{O}_{2}, 442.3811$ ).

Astataricusone C (3): white powder; $[\alpha]_{\mathrm{D}}^{22.8}-18.6$ (c 0.80, MeOH); UV (MeOH) $\lambda_{\max }(\log \varepsilon) 202(3.18) \mathrm{nm}$; $\mathrm{CD}(\mathrm{c} 0.64, \mathrm{MeOH}) \lambda(\Delta \varepsilon) 290(-7.8) \mathrm{nm}$; IR (KBr) $v_{\max }$ 3,533, 3,448, 2,933, 2,876, 1,711, 1,466, 1,387, 1,187, $972 \mathrm{~cm}^{-1}$; ${ }^{1} \mathrm{H}-\mathrm{NMR}\left(400 \mathrm{MHz}, \mathrm{CDCl}_{3}\right)$ and ${ }^{13} \mathrm{C}-\mathrm{NMR}\left(100 \mathrm{MHz}, \mathrm{CDCl}_{3}\right.$ ), see Tables 1 and 2; HREIMS $m / z$ 442.3824 [M] $]^{+}$(calcd. for $\mathrm{C}_{30} \mathrm{H}_{50} \mathrm{O}_{2}, 442.3811$ ).

Astataricusone D (4): white powder; $[\alpha]_{\mathrm{D}}^{23.1}-98.1$ (c 0.21, MeOH); UV (MeOH) $\lambda_{\max }(\log \varepsilon) 204(3.41) \mathrm{nm}$; $\mathrm{CD}$ (c 0.60, DMSO) $\lambda(\Delta \varepsilon) 290(-5.8), 300(-5.7) \mathrm{nm}$; IR (KBr) $v_{\max }$ 3,475, 3,443, 2,934, 1,701, 1,466, 1,388, $1,072 \mathrm{~cm}^{-1}$; ${ }^{1} \mathrm{H}-\mathrm{NMR}\left(400 \mathrm{MHz}, \mathrm{CDCl}_{3}\right)$ and ${ }^{13} \mathrm{C}-\mathrm{NMR}\left(100 \mathrm{MHz}, \mathrm{CDCl}_{3}\right)$, see Tables 1 and 2; HREIMS $m / z 460.3922[\mathrm{M}]^{+}$(calcd. for $\mathrm{C}_{30} \mathrm{H}_{52} \mathrm{O}_{3}, 460.3916$ ).

Astataricusol A (5): white powder; $[\alpha]_{\mathrm{D}}^{23.1}-19.0$ (c 0.25, MeOH); UV (MeOH) $\lambda_{\max }(\log \varepsilon) 193$ (2.56), 202 (2.99) nm; CD (c 0.63, MeOH) $\lambda(\Delta \varepsilon) 290(-0.8) \mathrm{nm}$; IR (KBr) $v_{\max }$ 3,439, 2,941, 2,925, 1,631, 
1,463, 1,376 $\mathrm{cm}^{-1}$; ${ }^{1} \mathrm{H}-\mathrm{NMR}\left(400 \mathrm{MHz}, \mathrm{CDCl}_{3}\right)$ and ${ }^{13} \mathrm{C}-\mathrm{NMR}\left(100 \mathrm{MHz}, \mathrm{CDCl}_{3}\right)$, see Tables 1 and 2; HREIMS $m / z 444.3973[\mathrm{M}]^{+}$(calcd. for $\mathrm{C}_{30} \mathrm{H}_{52} \mathrm{O}_{2}, 444.3967$ ).

\subsection{X-ray Crystallographic Analysis}

The intensity data for astataricusone A (1) was collected on a Bruker APEX DUO diffractometer using graphitemonochromated $\mathrm{CuK} \alpha$ radiation. Its structure was solved by direct methods (SHELXS97), expanded using difference Founier techniques, and refined by the program and full-matrix least-squares calculations. The nonhydrogen atoms were refined anisotropically, and hydrogen atoms were fixed at calculated positions. Crystallographic data for the structure of $\mathbf{1}$ has been deposited in the Cambridge Crystallographic Data Centre (deposition number CCDC 926578). Copies of the data can be obtained free of charge from the CCDC via www.ccdc.cam.ac.uk. $\mathrm{C}_{30} \mathrm{H}_{50} \mathrm{O}_{2}$, $M=442.70$, orthorhombic, $a=15.1404$ (2) $\AA, b=23.8310$ (3) $\AA, c=7.25500$ (10) $\AA, \alpha=90.00^{\circ}$, $\beta=90.00^{\circ}, \gamma=90.00^{\circ}, V=2617.68(6) \AA^{3}, T=100(2) \mathrm{K}$, space group $P 2{ }_{1} 2_{1} 2_{1}, Z=4$, $\mu(\mathrm{CuK \alpha})=0.510 \mathrm{~mm}^{-1}, 12841$ reflections measured, 4644 independent reflections $\left(R_{\text {int }}=0.0414\right)$. The final $R_{l}$ values were $0.0499(I>2 \sigma(I))$. The final $w R\left(F^{2}\right)$ values were $0.1382(I>2 \sigma(I))$. The final $R_{l}$ values were 0.0505 (all data). The final $w R\left(F^{2}\right)$ values were 0.1392 (all data). The goodness of fit on $F^{2}$ was 1.064 . Flack parameter $=0.1(3)$. The Hooft parameter is $0.06(9)$ for 1887 Bijvoet pairs.

\subsection{Determination of Absolute Configuration of the 21,22-Diol Group in $\mathbf{4}$}

According to the procedure [18], the first CD spectrum $\left(\mathrm{CD}_{1}\right)$ of the 1:1.2 mixture of $4: \mathrm{Mo}_{2}(\mathrm{OAc})_{4}$ at the concentration of $0.95 \mathrm{mg} / \mathrm{mL}$ in DMSO was recorded after mixed immediately. Then the second $\mathrm{CD}$ spectrum $\left(\mathrm{CD}_{2}\right)$ was recorded at $30 \mathrm{~min}$ after mixed. Finally the induced $\mathrm{CD}$ (ICD) of 4 was calculated by the formula: $\mathrm{ICD}=\mathrm{CD}_{2}-\mathrm{CD}_{1}$.

\section{Conclusions}

Five new shionane-type triterpenes 1-5, named astataricusones A-D (compound 1-4) and astataricusol A (5), were isolated from Aster tataricus, together with a known one 6. According to previous investigations on Aster species, we have evaluated the inhibitory activities of all compounds against the secretion of HBV antigen and DNA replication from the HepG 2.2.15 cell line. Compounds $\mathbf{2}$ and $\mathbf{6}$ showed significant anti-HBV activity. The results prove the potential for the use of this plant as a herbal medicine in the treatment of HBV.

\section{Supplementary Materials}

${ }^{1} \mathrm{H}-\mathrm{NMR},{ }^{13} \mathrm{C}-\mathrm{NMR}$ and MS spectra of $\mathbf{1 - 5}, \mathrm{CD}$ of $\mathbf{1 - 6}$, and X-ray crystallographic data for $\mathbf{1}$ are available as supporting data, which can be accessed at: http://www.mdpi.com/1420-3049/18/12/14585/s1.

\section{Acknowledgements}

This work was supported by the National New Drug Innovation Major Project of China (2011ZX09307-002-02), the National Natural Science Foundation of China (U1032602, 91013002, 
21102152), the Natural Science Foundation of Yunnan Province (2012GA003 and 2011FZ206), and the Foundation of Chinese Academy of Sciences (Hundred Talents Program).

\section{Conflicts of Interest}

The authors declare no conflict of interest.

\section{References}

1. Sawai, S.; Uchiyama, H.; Mizuno, S.; Aoki, T.; Akashi, T.; Ayabe, S.-I.; Takahashi, T. Molecular characterization of an oxidosqualene cyclase that yields shionone, a unique tetracyclic triterpene ketone of Aster tataricus. FEBS Lett. 2011, 585, 1031-1036.

2. Patil, F.; Ourisson, G.; Tanahashi, Y.; Takahashi, T. Shionone structural study. II. Bull. Soc. Chim. Fr. 1964, 6, 1422-1423.

3. Takahashi, T.; Moriyama, Y.; Tanahashi, Y.; Ourisson, G. The structure of shionone. Tetrahedron Lett. 1967, 8, 2991-2996.

4. Ireland, R.E.; Kowalski, C.J.; Tilly, J.W.; Walba, D.M. Total synthesis of terpenes. XX. Total synthesis of ( \pm )-shionone, a tetracyclic triterpene. J. Org. Chem. 1975, 40, 990-1000.

5. Ireland, R.E.; Lipinski, C.A.; Kowaiski, C.J.; Tilley, J.W.; Walba, D.M. Total synthesis of dl-shionone, a tetracyclic triterpene. J. Am. Chem. Soc. 1974, 96, 3333.

6. Zhao, S.M.; Kuang, B.; Peng, W.W.; He, W.J.; Xu, H.M.; Ji, C.J.; Han, J.; Zheng, Y.Q.; Song, W.W.; Tan, N.H. Chemical progress in cyclopeptide-containing traditional medicines cited in Chinese pharmacopoeia. Chin. J. Chem. 2012, 30, 1213-1215.

7. Lai, G.F.; Chen, J.J.; Luo, S.D. Advances in the studies of chemical constituents and pharmacological activities of Aster L. Nat. Prod. Res. Dev. 2002, 14, 65-70.

8. Lu, Y.H.; Dai, Y.; Wang, Z.T. Polyphenolic compounds from Aster tataricus. Chin. Tradit. Herbal Drugs 1999, 30, 360-362.

9. Zhou, W.B.; Tao, J.Y.; Xu, H.M.; Chen, K.L.; Zeng, G.Z.; Ji, C.J.; Zhang, Y.M.; Tan, N.H. Three new antiviral triterpenes from Aster tataricus. Z. Naturforsch. 2010, 65b, 1393-1396.

10. Tan, N.H.; Zhou, J. Plant cyclopeptides. Chem. Rev. 2006, 106, 840-895.

11. Xu, H.M.; Yi, H.; Zhou, W.B.; He, W.J.; Zeng, G.Z.; Xu, W.Y.; Tan, N.H. Tataricins A and B, two novel cyclotetrapeptides from Aster tataricus, and their absolute configuration assignment. Tetrahedron Lett. 2013, 54, 1380-1383.

12. Xu, H.M.; Zeng, G.Z.; Zhou, W.B.; He, W.J.; Tan, N.H. Astins K-P, six new chlorinated cyclopentapeptides from Aster tataricus. Tetrahedron 2013, 69, 7964-7969.

13. Shen, Y.; Luo, Q.; Xu, H.M.; Gong, F.Y.; Zhou, X.B.; Sun, Y.; Wu, X.F.; Liu, W.; Zeng, G.Z.; Tan, N.H.; et al. Mitochondria-dependent apoptosis of activated T lymphocytes induced by astin C, a plant cyclopeptide, for preventing murine experimental colitis. Biochem. Pharmacol. 2011, 82, 260-268.

14. Yan, F.L.; Yao, S.M.; Zhou, Y. Two new tetracyclic triterpenoids and other constituents from Aster ageratoides var. oophyllus. J. Chin. Chem. Soc. 2007, 54, 1321-1324. 
15. Toshihiro, A.; Yumiko, K.; Kazuo, K.; Takaaki, T.; Ken, Y.; Koichi, A.S.; Tamotsu, N.Y. Astertarone A: A triterpenoid ketone isolated from the roots of Aster tataricus L. Chem. Pharm. Bull. 1998, 46, 1824-1826.

16. Tanahashi, Y.; Moriyama, Y.; Takahashi, T.; Patil, F.; Biellmann, J.-F.; Ourisson, G. Structure of shionone. III. Side chain. Bull. Soc. Chim. Fr. 1966, 5, 1670-1677.

17. CCDC 926578 (1) contains the supplementary crystallographic data. Available online: www.ccdc.cam.ac.uk/cgi-bin/catreq.cgi?access=referee/ (accessed on 20 November 2013).

18. Politi, M.; de Tommasi, N.; Pescitelli, G.; di Bari, L.; Morelli, L.; Brace, A. Structure and absolute configuration of new diterpenes from Lavandula multifida. J. Nat. Prod. 2002, 65, 1742-1745.

19. Snatzke, G. Circular dichroism and absolute conformation: Application of qualitative MO theory to chiroptical phenomena. Angew. Chem. Int. Ed. Engl. 1979, 18, 363-377.

20. Kim, T.G.; Kang, S.Y.; Jung, K.K.; Kang, J.H.; Lee, E.; Han, H.M.; Kim, S.H. Antiviral activities of extracts isolated from Terminalis chebula Retz., Sanguisorba officinalis L., Rubus coreanus Miq. and Rheum palmatum L. against hepatitis B virus. Phytother. Res. 2001, 15, 718-720.

21. Li, H.B.; Zhou, C.X.; Zhou, L.F.; Chen, Z.; Yang, L.X.; Bai, H.; Wu, X.M.; Peng, H.; Zhao, Y. In vitro antiviral activity of three enantiomeric sesquiterpene lactones from Senecio species against hepatitis B virus. Antivir. Chem. Chemother. 2005, 16, 277-282.

22. Han, H.J.; Tan, N.H.; Zeng, G.Z.; Fan, J.T.; Huang, H.Q.; Ji, C.J.; Jia, R.R.; Zhao, Q.S.; Zhang, Y.J.; Hao, X.J.; et al. Natural inhibitors of DNA topoisomerase I with cytotoxicities. Chem. Biodivers. 2008, 5, 1364-1368.

Sample Availability: Samples of the compounds 1-6 are available from the authors.

(C) 2013 by the authors; licensee MDPI, Basel, Switzerland. This article is an open access article distributed under the terms and conditions of the Creative Commons Attribution license (http://creativecommons.org/licenses/by/3.0/). 